\title{
TRANSACTIONS OF THE
}

\section{INTERNATIONAL ASTRONOMICAL UNION VOLUME VIII}

\author{
EDITED BY \\ P. TH. OOSTERHOFF \\ ROYAL 8 Vo; 896 PP.; PLATES AND TEXT-FIGURES
}

The eighth volume of Transactions of the International Astronomical Union contains financial reports and reports of the Union's activities from the Executive Committee for the years 1948-1951. An account is given of the Eighth General Assembly of the I.A.U.held in Rome in September 1952.

A considerable part of the volume is devoted to reports by the presidents of the thirty-nine standing commissions, each of which covers a special branch of astronomy. These reports provide valuable information on the development of astronomy in the last four years. They also give a detailed account of the meeting of these commissions during the Rome Congress.

Besides general information about the organization and officers of the Union, the Transactions contains the synopses of three symposia, organized for the Rome Congress. The subjects of these symposia are stellar evolution, astronomical instrumentation, and the problems of astronomy of faint stars.

\section{CAMBRIDGE UNIVERSITY PRESS}

Bentley House, 200 Euston Road, London, N.W. I American Branch: 32 East $57^{\text {th }}$ Street, New York 22, N.Y. 